\title{
The regional employment effects of new social firm entry
}

\author{
Habib Kachlami • Per Davidsson • Martin \\ Obschonka • Darush Yazdanfar • Anders Lundström
}

Accepted: 1 April 2020 / Published online: 8 May 2020

(C) The Author(s) 2020

\begin{abstract}
As a contribution to research and theorizing on the economic role of new firm formation, we undertake the first ever investigation of regional employment effects of the entry of new social firms. Our study is guided by an established model of the employment effects of new firm entry over time and provides a direct comparison to the employment effects of commercial entrants. Our results show that the net employment effect of new social firms follows a wave pattern over
\end{abstract}

H. Kachlami $(\bowtie) \cdot$ D. Yazdanfar

Centre for Research on Economic Relations, Mid Sweden

University, Sundsvall, Sweden

e-mail: habib.m.kachlami@miun.se

\section{Yazdanfar}

e-mail: darush.yazdanfar@miun.se

P. Davidsson - M. Obschonka

Australian Centre for Entrepreneurship Research, Queensland

University of Technology, Brisbane, Australia

P. Davidsson

e-mail: per.davidsson@qut.edu.au

M. Obschonka

e-mail: martin.obschonka@qut.edu.au

P. Davidsson

Jönköping International Business School, Jönköping, Sweden

\section{A. Lundström}

The Institute of Innovative Entrepreneurship, Stockholm, Sweden e-mail: anders@ipreg.se the study's eight-year horizon, apparently produced by the same combination of direct and indirect effects previously theorized for new commercial entrants. The results also indicate that net employment effect per social firm entrant is larger than for commercial firms. The study provides a first empirical assessment of employment creation effects of new social firms and contributes to a more nuanced theoretical understanding of employment effects across types of entrants. By specifying the economic contribution of social firms our study can open up a new track in social entrepreneurship research and provide important input to employment policy.

Keywords Social entrepreneurship - Employment . Firm formation · Entry · Start-up · New firm · Regional development $\cdot$ Sweden

JEL classifications $\mathrm{E} 24 \cdot \mathrm{M} 13 \cdot \mathrm{L} 26 \cdot \mathrm{L} 31 \cdot \mathrm{R} 11$

\section{Introduction}

Who creates jobs? There is broad consensus that particularly young and small firms make important contributions to job creation and growth (e.g., Haltiwanger et al. 2013). This has spurred a massive research interest in startups (new firm entry) and their economic effects, not only to better quantify the nature and conditions of the economic effects but also to inform industrial policies more effectively, for example what type of new firms 
should be promoted (Audretsch et al. 2007; Birch 1981, 1987; Kirchhoff 1994).

With respect to the type of new firms that delivers particularly strong employment effects, existing research mainly focused on commercial new firms. In contrast, potential employment effects of new social firms are poorly understood. The category of social firms includes organizations of varying age and size, a range of governance arrangements, and social missions ranging from altruistic to environmental. Their common ground is that they are formed around a social mission, economic goals and constraints being secondary concerns (Austin et al. 2012; Dacin et al. 2010; Defourny and Nyssens 2010; Hoogendoorn et al. 2010; Peredo and McLean 2006; Zahra et al. 2009). Conversely, although commercial firms may generate social benefits, these are collateral to their main mission. No prior study has separately investigated the net employment effect of social firms. We therefore undertake the first empirical study of the regional level employment dynamics of new social firms and directly compare their employment effects over time to those of new commercial firms. The research question we address is "How do new social firm entrants contribute to regional employment creation over time, and how does their contribution compare to that of new commercial firms?"

Given that there is no established theoretical framework for the specific case of employment effects of new social firms, we draw on the general job creation literature with its focus on commercial new firms. In this literature, Fritsch and Mueller's (2004, 2008, see also Fritsch, 2008) model of direct and indirect effects over time has become a leading and influential approach to understanding employment effects of new firms (Andersson and Noseleit, 2011; Arauzo Carod et al. 2008; Acs and Mueller 2008; Baptista et al. 2008; van Stel and Suddle 2008). An important insight from Fritsch and Mueller's (2004) groundbreaking study was that the employment effect of new firms follows a wave pattern over time with the net result being either positive or negative depending on a combination of effects that are both direct and indirect. We decided to take Fritsch and Mueller's (2004) model and theorizing as a conceptual starting point for our investigation, in addition to existing knowledge of distinguishing features of social firms, compared to commercial firms (see Austin et al., 2012; Mair and Marti 2006).

Given that Fritsch and Mueller's (2004) study, and several following studies (e.g., Arauzo Carod et al.
2008; Audretsch and Fritsch 2002; Carree and Thurik 2010; Fritsch and Mueller 2008; Fritsch and Noseleit 2013; van Stel and Storey 2004), also made clear that it is essential to examine longer periods of time to understand and capture employment effects of new firms, we consider a longer time horizon in our study. Specifically, we overcome the dearth of data that has hampered research on the employment effects of new social firms (Barbetta et al. 2018) by using a large-scale, firm level dataset covering 67 local labor markets in Sweden between 1990 and 2014, and using a non-profit legal form not allowed for commercial firms to represent social firms. Although employment effects could in principle be investigated by comparing countries or time periods, we conduct the analysis on the regional level following the practice of prior research and in accordance with most social firms being locally embedded ventures that target local social problems (Clarence and Noya 2009).

An investigation of employment effects of social firm entry is important for at least three major reasons. First, by revealing what is similar and what is not, direct comparison of employment effects of social and commercial entry over time provides a more detailed picture of employment effects of new entry, which can inform interpretation and simulate new ideas regarding the well-established temporal pattern of employment effects of new entry in general. This provides insight into boundary conditions and a basis for theoretical development in this otherwise empirically oriented domain of research. For example, our investigation helps clarifying whether the employment effects of new social firms are consistent with the theorizing on employment effects of new firms in general (e.g., Fritsch and Mueller, 2004). Second, insights from our study provide input to policymaking. Social firms constitute a large and growing sector in many economies and have a significant role in welfare policies around the world (Nicholls 2010; Seelos et al. 2011) including employment policies (Dees 2007; OECD 2013). Among other things, social firms are likely to be disproportionately important for employment in marginalized groups like people with disabilities and long-term unemployed individuals. Third, by focusing on social firms' employment effects we highlight their economic value and not only their social value with which most previous research was concerned. This can inspire new developments in social entrepreneurship research investigating other aspects of economic value creation by social firms. 
As this is the first study on the topic and there are arguments both for and against the employment effects of new social firms mirroring those of commercial entrants, we refrain from stating specific hypotheses about the employment effects of social firm entry. Instead, we approach the issue in an exploratory manner, using the general model developed by Fritsch and Mueller (2004) for the employment effects of commercial firms as the starting point of our exploration.

The paper is structured as follows. Section 2 outlines our theoretical vantage points, i.e., Fritsch and Mueller's (2004, 2008) theorizing about three types of effects creating a wave-pattern for new firms' contribution to regional employment creation over time, and prior knowledge about similarities and differences between commercial and social firms. Section 3 explains the data set, variables, and analysis approaches used in the study. Section 4 presents the results regarding the effects of new social firms on regional employment creation over an extended period of time. The paper ends with a Discussion (Sect. 5) addressing the study's contributions, implications, and limitations as well as opportunities for future research, and a brief conclusion (Sect. 6). Supplementary, descriptive statistics are provided in appendices.

\section{Theoretical framework: the Fritsch-Mueller model and job creation by new social firms}

In contrast to earlier research investigating the numbers of jobs created within new entrants themselves over relatively short time spans, Fritsch and Mueller (2004) applied a true regional perspective, considering also effects on other firms and over a longer period of time. Specifically, they investigated the employment effects of new commercial firms over 10 years through incorporating successive annual lags of start-up rates in their model. They concluded that the regional employment effect of new firms follows a wave pattern over time with the net outcome being either positive or negative (see Fig. 1).

Fritsch and Mueller (2004, 2008, Fritsch, 2008) argued that this net effect depends on a combination of direct and indirect effects. The direct (or immediate) effect is positive and consists of the new employment created by the entrants themselves through initial hiring, retention, and eventual expansion of their work force. The indirect effects fall into two categories: the

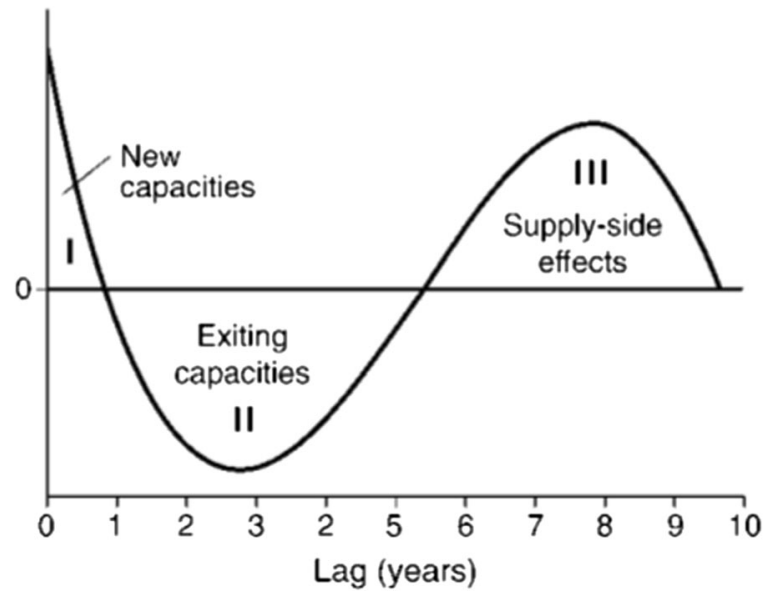

Fig. 1 The direct and indirect effects of new commercial firms on regional employment growth. Source: Fritsch and Mueller (2004)

displacement effect and the supply-side effect. ${ }^{1}$ The displacement effect, which is negative, arises from some incumbent firms shrinking or exiting the market (along with the less successful of the recent entrants) as a result of new competition from the (better among the) entrants. Since entry is expected to be productivity-enhancing, this should lead to a negative total effect on employment, which is indeed what is often observed in the medium term.

However, as Fritsch (2008: 3) points out, the market process is not a zero-sum game, in which one economic actor's gain is completely at the expense of other actors. The supply-side effect, which typically takes longer time to evolve, is a composite of even more dispersed effects on the level of the (industry- and regional level) economic system. One important component is that entry drives improvements in efficiency and productivity. According to Fritsch and Mueller (2004) the entry of new firms can secure efficiency or stimulate productivity through contesting established market positions. Beyond the medium-term displacement of less productive firms, productivity-enhancing entrants lead to more competitive and therefore more profitable firms in the regional economy. This provides a basis for profitable growth (cf. Davidsson et al. 2009), leading to a positive effect on employment in the longer run.

\footnotetext{
1 "Indirect effect" as used by Fritsch and Mueller (2004) is not the same as "employment multiplier" effects in other strands of research. The latter refers to additional jobs created due to the entry of new firm in a region (Moretti 2010). Fritsch and Mueller's use refers to both jobs added and lost elsewhere in the economy as a result of a new entrant, whether within the value chain, by crowding out competitors, or by inspiring other entrants to follow suit.
} 
Other components of the supply-side effect include that entry of new firms can accelerate structural change in the market through the turnover of the respective economic units, i.e. entry of new firms and exit of old incumbents (creative destruction). Further, new firms can generate qualitative development of the regional economy through amplified innovation and greater variety of products and problem solutions. Accordingly, the supply-side effect does not only emerge from the survival and success of entrants, but also improvements among incumbent firms in the regional economy more generally. This includes sometimes substantial positive effects of entrants that do not survive but nevertheless stimulate important improvements in other firms (cf. Davidsson, 2016: 12-13).

Depending on the relative size of these direct and indirect effects, the employment effect of new firm entry can be either positive, negative, or neutral. Although direct assessment of the indirect effects is challenging, the wave pattern in Fig. 1 is consistent with direct effects operating immediately and continuing over time; displacement effects becoming pronounced in the mediumterm, and supply-side effects taking somewhat longer time before they peak. Results consistent with this wave pattern and interpretation have been reported in a number of studies employing Fritsch and Mueller's (2004) framework in other contexts (e.g., Acs and Mueller 2008; Baptista et al. 2008; Mueller et al. 2008; van Stel and Suddle 2008).

While this theorization and accompanying empirical support resolve the puzzle of alternating positive and negative employment effects of entry recorded in earlier research, they do not distinguish commercial from social firms. Can we also apply this model to quantify and understand net employment effects of new social firms? What does past research say about the employment creation of social firms and about what characteristics distinguish them from social firms? Does what we know suggest that applying the Fritsch-Mueller logic to new social firms makes sense? This is what we turn to next.

There are a few descriptive studies of aggregate data suggesting that the expansion of the social sector is associated with employment increase (e.g., Casey 2016; Sivesind 2017; Enjolras and Strømsnes 2018). Although this could be an effect of growth in other sectors rather than an independent source of employment growth, data also suggest that the social sector has grown faster than other sectors in some countries. In Salamon and Sokolowski's (2018) study within the
European Union, the social sector's annual employment growth rate was $3.4 \%, 0.6$ percentage higher than the employment growth of the economy as a whole. Similarly, Salamon (2012) reported that during 2000 to 2010 , employment in the nonprofit social sector in the US grew by $2.1 \%$ annually, whereas employment in commercial firms shrank by $0.6 \%$ in the same period. This suggests that the social sector's unique employment contribution is not just a reflection of growth in other sectors.

We know little, however, about the employment creation dynamics of the social sector. Studies on the entry and exit of social firms are few, often non-empirical, and largely focused on topics other than employment dynamics, such as explaining the fundamental origin of and rationale for the social sector (Archambault et al. 2014; Andersson and Ford 2016; Hansmann 1980, 1987; Kachlami et al. 2018; Lecy and Van Slyke 2013; Twombly 2003; Weisbrod 1977). Some have focused on specific behaviors of social firms (e.g., Harrison and Laincz 2008; Harrison and Thornton 2014; Barbetta et al. 2018), but none has investigated the employment effects over time of social firm entry.

Research has established differences between social and commercial firms and their founders which may influence their employment effects of commercial start-ups. Apart from their central mission, social and commercial firms differ also in other regards, such as the demographic and socio-economic characteristics of founders (Harding and Cowling 2006; Bacq et al. 2013; Kachlami et al., 2018; Parker 2018), and how they approach resource mobilization (Austin et al., 2012; Mair and Marti 2006). These and other differences may influence their direct and indirect employment creation prowess.

Further, one could argue that social firms typically enter far-from-saturated "markets" of social needs and that they do not compete with each other (or with commercial firms) to the same extent as is the case in commercial markets. This would reduce any productivity-based mechanism fueling indirect job creation. At the same time, this argument also goes against negative job effects via displacements. It can also be argued that social firm entrants are usually small, poorly resourced, and relying to a great extent on volunteer work. This would suggest low levels of direct job creation effects by the entrants themselves. On the other hand, commercial entrants are similarly dominated by a "modest majority" of low-ambition, low-potential 
businesses (Davidsson and Gordon 2012) that create few jobs directly on a per capita basis. Few commercial entrants are backed up by significant financial capital and may neither be aiming nor suited for substantial growth (Aldrich and Ruef, 2018; Wiklund et al., 2003). Thus, starting (and staying) small and resourcepoor may not distinguish social firm entrants from commercial ones.

This is only one aspect of how differences between social and commercial ventures are sometimes exaggerated. For example, social firms' revenue generation is not as different as many observers may think. In fact, a very small share consists of charitable contributions and a significant share of earned income (Salamon and Sokolowski 2018). Within Europe, donations and charitable contributions account for only $9 \%$ of social firms' revenue, while earned income from products, services and membership fees amount to a much larger share of their revenue (Salamon and Sokolowski 2018). For some social firms like Work Integration Social Enterprises (WISE), earned income reaches $80 \%$ of their revenue (Vidal 2005). Recent developments in social entrepreneurship and increased emphasis on market solutions for social problems has even made the dual mission of social value creation and financial sustainability the defining characteristics of social firms (Garrow and Hasenfeld 2014). As a result, social firms have increasingly entered into competition with other actors in the market. Empirical studies confirm this competition (Fauchart and Gruber 2011; Harrison and Laincz 2008; Kachlami 2016, 2017).

Thus, while there are undeniable differences between social and commercial firms, they do not point unambiguously in one direction, especially considering the combination of direct and indirect effects over time. At the same time, it seems likely that all the effects discussed by Fritsch and Mueller (2004, 2008) would operate to some degree, albeit to different extents-and possibly different timing - compared to commercial entrants. Therefore, we think it is informative to apply the Fritsch-Mueller framework to investigate the unknown territory of employment effect of social firms and to compare them to those of commercial firms. Research on the young field of social entrepreneurship has traditionally borrowed from the closely related field of commercial entrepreneurship. According to Henry et al. (2013) research into social entrepreneurship can progress more quickly if the knowledge acquired from commercial entrepreneurship studies is applied.

\section{Method}

\subsection{Data}

According Short et al.'s (2009) review study, data collection is the biggest challenge of scholars of social entrepreneurship. In particular, investigating entry, survival and migration of firms requires firm level data which are rarely available for social firms (Barbetta et al. 2018). Data for this study originate from 290 municipalities across Sweden between 1990 and 2014. The data were collated from Statistics Sweden (Statistiska Centralbyrån, SCB), the official organization for collecting statistical data in Sweden. Information from several of their databases were integrated to create the data set for this study. ${ }^{2}$

Using Swedish data is suitable for several reasons. First, Sweden is one of the countries that has relatively complete and detailed longitudinal data sets on firm births. Accordingly, the employment dynamics of new commercial firms in the Swedish context have been investigated in several previous studies (e.g., Andersson and Noseleit 2011; Borgman and Braunerhjelm 2007; Davidsson et al. 1994; Fölster 2000). Second, Sweden also has a growing social sector that accounts for a significant and growing employment share (Lundström and Svedberg 2003; Enjolras and Strømsnes 2018; Salamon and Sokolowski 2018). Third, and most importantly, the data allow separate analysis of social firms. This will be detailed further below.

The data are aggregated to the level of local labor markets ("lokala arbetsmaknader") for statistical analysis. Statistics Sweden define local labor markets based on the rate of commuting between municipalities. Each labor market consists of a core municipality and several surrounding municipalities which have their highest rate of commuting with the core municipality. Because commuting patterns change, the classification is updated at regular intervals. There were 73 local labor markets in Sweden in 2014. In the analyses, we exclude six small labor markets that were not present during the whole

\footnotetext{
$\overline{{ }^{2} \text { Specifically, data regarding the entry of new social and commercial }}$ firms come from FDB (företagdatabasen; the "company register") which captures all entry and exit of organizations in all the municipalities across Sweden. The data for employment comes from RAMS (registerbaserade arbetsmarknadstatistik; "register-based labor statistics") which contains data about the employment of the entire population between 16 and 74 years old. The division into local labor markets originates from other Statistics Sweden sources.
} 
analysis period. The analyses are thus based on 67 labor markets representing the vast majority of the Swedish population, economy, and land mass. As some data are missing due to administrative-territorial reforms during the analysis period and also some missing values for particular variables, we have 1273 region-year observations in our panel data set.

\subsection{Variables}

The dependent variable in this study is regional employment change. It is measured over two-year periods, as is the norm in most of the prior research (e.g., Arauzo Carod et al. 2008; Baptista and Preto 2011; Fritsch and Mueller 2008; Fritsch and Schindele 2011), to avoid the disturbances of short-term, random fluctuations. ${ }^{3}$ As shown in the following equation, it is computed as a percentage of employment change over 2 years, i.e.,

Employment change $e_{t}$

$$
=\frac{\left(\text { Employment }_{t}-\text { Employment }_{t-2}\right)}{\text { Employment }_{t-2}} * 100
$$

The central independent variable is the start-up rate of social firms. To make the start-up rates of social firms comparable across all the 67 labor markets, the number of new social firms in each labor market is divided by the total workforce in that labor market (in thousands) at the start of the period. ${ }^{4}$ Data for social firms comprise ventures registered under the legal form "ideella föreningar" (nonprofit associations) in Sweden during 1990-2014. Firms registered under the "ideella" legal form are nonprofit firms with a purely social mission and thus provide an appropriate proxy for social firms in this study. Firms under this legal form do not conduct activities that economically benefit their members. They can undertake a broad range of market-oriented, economic activities (both tax-exempted and taxed), but the profit resulting from these activities cannot be paid to

\footnotetext{
${ }^{3}$ We also conducted a sensitivity analysis by changing employment change from two-year to three-year period. The results were substantially similar and are available upon request.

${ }^{4}$ For more information on different approaches of normalizing start-up rate, see Audretsch and Fritsch (1994). Some studies on commercial firms normalize the firm formation rate based on the composition of industries in regions, a method known as shift-share procedure (e.g., Baptista et al. 2008; Fritsch and Mueller 2008; Fritsch and Schroeter 2011). This method, however, is not applied in this study since social firms are not influenced by the industry structure as much as commercial firms. For further information about shift-share procedure, see Audretsch and Fritsch (2002).
}

the members as dividends. Although social firms can operate under other legal forms, commercial firms cannot operate under the "ideella föreningar" legal form. Hence, the social firm start-ups in our study are a substantial and relatively pure subset of all social firm startups.

We control for other factors that can influence regional employment. The main control variable used by most of the previous research has been population density (e.g., Fritsch and Mueller 2004; Fritsch and Mueller 2008; Mueller et al. 2008). Population density is known to be a catch-all control variable that correlates highly with many regional characteristics such as labor market diversity, workforce qualification, communication infrastructure, real estate prices, industry structure, and income level, all of which may affect regional entrepreneurship and employment growth (Fritsch and Mueller 2004; Fritsch and Mueller 2008). Thus, in this study we also include population density in our model. Moreover and most importantly, we also control for the region's rate of commercial start-ups. Without this control, if entry in commercial and social sectors is correlated, any results could easily be due to the dynamics of the much larger commercial sector. Inclusion of commercial entry also allows us to directly compare employment effects of new social vs. commercial firms. Our controlling for the commercial firm start-up rate takes the form of controlling for the entire lag structure before we enter the current and lagged social firm start-up rate variables. To control for region-specific factors other than those captured by our control variables, we employ the fixedeffect method for analysis.

\subsection{Analysis approach}

Investigating the employment effects of new social firms over time requires a model with time lags relating the current employment change to the start-up rate of the current year and of several preceding years. However, the longer the lags used, the fewer years are available for analysis. Previous studies on commercial firms have anything from a five-year lag (e.g., Andersson and Noseleit 2011) to a 10-year lag (e.g., Fritsch and Mueller 2004; Fritsch and Mueller 2008). According to Fritsch and Mueller (2004), the positive effect of new commercial firms on regional employment creation reaches its peak 8 years after entry. Fritsch and Mueller (2008) also noted that they would have reached the same result if a time lag of 8 years (instead of 10 years) were applied. 
Therefore, we apply a model, shown in Eq. 1, where the current regional employment change is related to the start-up rates of social firms in the current year and the eight preceding years. In Eq. $1, \Delta E_{r, t}$ denotes the percentage change in total employment in the labor market region $r$ during the two-years periods of $t$ and $t-2$. $S_{c, r}$, ${ }_{t-\tau}$ and $S_{S, r, t-\tau}$ denote the startup rates of commercial and social firms in labor market region $r$ respectively, while $\tau$ denotes the lag length and $X$ is the vector of control variables.

$$
\begin{aligned}
\Delta E_{r, t}= & \sum_{\tau=0}^{8} \beta_{c, t-\tau} S_{c, r, t-\tau}+\sum_{\tau=0}^{8} \beta_{s, t-\tau} S_{s, r, t-\tau} \\
& +X_{r, t-1} \lambda+\alpha_{r}+\varepsilon_{r, t}
\end{aligned}
$$

Equation (1) is estimated using the fixed-effect method. Including longer time lags has the consequence of yielding high correlations among the start-up rates of the successive years making the estimated coefficients unreliable if based on the ordinary least square method (Fritsch 2015). Thus, to overcome the problem of multicollinearity, we apply the polynomial lag technique developed by Almon (1965). The Almon polynomial lag procedure tries to approximate the lag structure with a polynomial function to reduce the effects of multicollinearity (Greene 2008). An important issue in applying the Almon method is to identify the polynomial order that leads to the best estimation. Previous studies on commercial firms have identified the third order polynomial as providing the best estimation (e.g,. Fritsch and Mueller 2004; van Stel and Suddle 2008). Thus, we keep the third order polynomial for commercial firms and search for the best polynomial order for the lag structure of new social firms in a second step.

\section{Results}

The results of our statistical analysis contain both descriptive statistics and the estimation results. Descriptive statistics are presented in Tables 3, 4, and 5 of Appendices 1 and 2, while the estimation results are presented in Table 1 and Fig. 2 of this section. Appendix 1 provides an overview of the distribution of the important variables of this study, i.e., 2-year employment change, commercial start-up rate and social start-up rate, across time and space. As shown in Table 3, most of the labor markets with the highest average employment growth are located in the southern part of Sweden (except
Umeå), while most labor markets with the lowest employment growth are located in the northern part. This largely reflects the overall patterns of population density and population growth in the country, which increase from north to south except for some distinct deviations. Table 3 also shows that Stockholm - the capital - is not among the 10 labor markets with the highest employment growth despite having the highest rate of commercial firm formation. In Table 4, the year 2010 has the highest rate of both social and commercial firm formation and the subsequent year, 2011, has the highest employment growth. The increase of start-ups in 2010 might be partly attributed to the introduction of new immigration policy in 2008 allowing immigrants to acquire permanent residence with only 2 years of selfemployment above a certain level of income. It can also be partly attributed to the recovery of the overall economy from the economic crisis of 2008. In Table 5, the high correlation among the lagged start-up rates of commercial firms confirms the regional persistence of commercial entrepreneurship reported by previous studies (e.g., Andersson and Koster 2011); however, such persistence could not be found among social firms. The correlations for annual commercial vs. social entry rates are positively correlated at moderate levels; approx. $0.2-0.3$.

Table 1 shows two models: model (a) includes only commercial start-up rates and model (b) includes both commercial and social start-up rates. As can be seen, the inclusion of social start-up rates in model (b) improves the estimation model and increases explanatory power by seven percentage points. That is, a substantial part of the changes in regional employment not explained by new commercial start-ups can be explained by new social firms. In assessing this result, it should be remembered that the social sector represents a much smaller fraction of the total economy compared to the commercial sector.

Figure 2 provides a graphical presentation of the results of model (b) through separate lines showing the employment effects of new social and new commercial firms. As can be seen, the employment effect of new commercial firms follows the wave pattern over time reported by previous research. More importantly, the employment effect of new social firms also follows a wave pattern over time, suggesting that both direct and indirect effects are at play. However, unlike Fritsch and Mueller (2004) but in line with Baptista et al. (2008), the employment effect does not peak within the 8-year time 
frame. Based on previous studies, it is reasonable to assume that the effect would eventually level off or even turn down rather than the curve continuing upward indefinitely.

Interestingly, except for a dip in year 6 (possibly exaggerated for stochastic reasons), the curve for social firms is markedly above the corresponding curve for commercial firms. This suggests that the positive net effect per entrant on regional employment is greater for social firms than for commercial firms.

The results presented in Table 1 and Fig. 2, however, can suffer from high multicollinearity since the start-up rates of subsequent years are highly correlated making the regression coefficients potentially unreliable (Greene, 2008). As explained above, we employ the Almon method to reduce this problem. Table 2 shows the result of the second, third and fourth order polynomial lags for social firms, holding commercial firms constant at the third order as suggested by prior research (e.g., Fritsch and Mueller 2004; Fritsch and Mueller 2008; Baptista et al. 2008; van Stel and Suddle 2008). Figure 3 provides a graphical representation of the results.

The log likelihood results from Table 2 show improvement from the second to fourth order polynomial lag. The improvement after the third order polynomial, however, is negligible. Thus, similar to commercial firms, we identify the third order polynomial to provide a suitable estimation of the lag structure of the employment effects of new social firms. The third order polynomial lag of new social firms, Fig. 3b, shows a wave pattern with increasing effect in the short-term until $t_{1}$, decreasing effect in the mid-term from $t_{2}$ to $t_{5}$, and an increasing effect in the long-term from $t_{6}$ to $t_{8}$. Across all time horizons, the estimated effect of social firm entry is positive and overall more so than for commercial firms. Accordingly, a main finding of this first study of the regional level net employment effect of new social firms is that the effect is positive and of substantial magnitude.

\section{Discussion}

\subsection{Theoretical interpretation of our results}

In this study, we applied the previously formulated framework developed by Fritsch and Mueller (2004) for the employment effects of new commercial firms to explore the employment effects of new social firms. Taken together, our results suggest that the employment effect of new social firms follows a similar wave pattern over time as has previously been suggested based on research on undifferentiated or 'commercial only' samples (Fig. 3b). This indicates that the same direct and indirect effects discussed by Fritsch and Mueller (2004) may be at work in the employment effects of new social firms. As discussed in Sect. 2, this similarity can be attributed to the revenue structure and the competitive behavior of social firms not being as markedly different from commercial firms as is sometimes believed. Our results also suggest that across all time horizons we cover, the net employment effect per social entrant exceeds that of commercial entrants and only briefly, if ever, turns negative (cf. Figs. 1, 2 , and 3 ). In the following, we interpret this in terms of the direct, indirect-displacement, and indirectsupply side effects suggested by Fritsch and Mueller (2004).

As regards the direct effect - employment created by the entrants themselves - there is one main reason to expect it to be smaller (contrary to our actual results) than for commercial firms. This is that social entrants may try to avoid hiring paid employees to the extent possible, instead relying on volunteers. This said, there are three compelling reasons suggesting the direct employment effect of social entrants may actually be larger than for commercial entrant. First, they operate in a less competitive and less profit-oriented environment, which may encourage hiring and retaining employees in a number of inter-related ways. It improves their prospects of survival, increasing their direct employment effect over time (cf. Harrison and Laincz, 2008; Lakdawalla and Philipson, 2006). The higher legitimacy of nonprofit social firms may even prevent commercial firms from aggressively competing against them due to fear of damaging their own public image (Bosma et al. 2011). Further, while they are likely to operate under sometimes severe cost constraints, the competitiondriven constraints that push toward increased labor productivity are not as pronounced as in the commercial sector. In addition, firms with a social mission may be less inclined to reduce employment at the first signs of redundancy. This tendency would be even more pronounced if providing employment (e.g., for members of marginalized groups) is part of the social mission. 
Table 1 Impact of new commercial and social firm formation on regional employment change

Two-year regional employment change \%

\begin{tabular}{|c|c|c|}
\hline & Model (a) & Model (b) \\
\hline Commercial start-up rate, current year & $0.4044 * * *(18.40)$ & $0.2358 * * *(4.19)$ \\
\hline Commercial start-up rate, year t-1 & $0.3163 * * *(10.30)$ & $0.1547 * *(2.02)$ \\
\hline Commercial start-up rate, year $\mathrm{t}-2$ & $0.0476(1.01)$ & $-0.0154(-0.23)$ \\
\hline Commercial start-up rate, year t-3 & $-0.0024(-0.04)$ & $-0.1028(-1.52)$ \\
\hline Commercial start-up rate, year t- 4 & $-0.5022 * * *(-3.11)$ & $-0.5947 * * *(-3.07)$ \\
\hline Commercial start-up rate, year t-5 & $-0.4345^{*}(-1.84)$ & $-0.4272(-1.52)$ \\
\hline Commercial start-up rate, year t- 6 & $-0.2255(-0.94)$ & $-0.2424(-1.08)$ \\
\hline Commercial start-up rate, year t-7 & $0.8444 * * *(5.31)$ & $0.7547 * * *(4.17)$ \\
\hline Commercial start-up rate, year t- 8 & $0.6707 * * *(4.32)$ & $0.5526 * * *(2.86)$ \\
\hline Social start-up rate, current year & & $1.1823 * * *(3.89)$ \\
\hline Social start-up rate, year t-1 & & $1.1760 * * *(3.71)$ \\
\hline Social start-up rate, year $\mathrm{t}-2$ & & $0.5068 * *(2.26)$ \\
\hline Social start-up rate, year t-3 & & $0.8848 * * *(5.46)$ \\
\hline Social start-up rate, year t-4 & & $0.7201(1.30)$ \\
\hline Social start-up rate, year t-5 & & $0.3089(0.45)$ \\
\hline Social start-up rate, year t-6 & & $-0.9899(-1.18)$ \\
\hline Social start-up rate, year t-7 & & $1.7076 * *(2.65)$ \\
\hline Social start-up rate, year t- 8 & & $2.2679 * * *(3.14)$ \\
\hline Population density & $0.0064 * *(2.18)$ & $0.0204 * * *(4.09)$ \\
\hline Constant & $-23.8686^{* * *}(-4.48)$ & $-29.8738 * * *(-5.80)$ \\
\hline$R^{2}$ & 0.43 & 0.50 \\
\hline$F$ & 500.43 & 1155.71 \\
\hline Log-likelihood & -2515.37 & -2469.67 \\
\hline No. of observations & 687 & 687 \\
\hline
\end{tabular}

Fixed effect estimates

*Significant at $10 \%$ level; **significant at $5 \%$ level; ***significant at $1 \%$ level

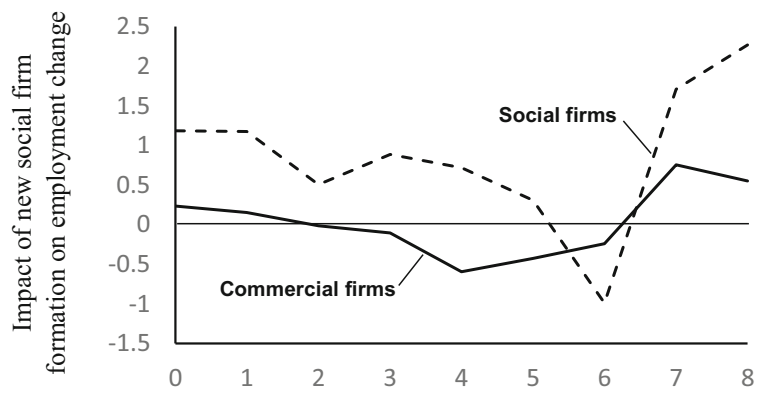

Fig. 2 The lag structure of the impact of both new commercial and social firms on regional employment change. a Second-order Almon polynomial lag of new social firms. b Third-order Almon polynomial lag of new social firms. c Fourth-order Almon polynomial lag of new social firms
Second, many social firms address insatiable social needs and are founded by individuals with a strong mission to alleviate suffering. This creates an impetus for growth that is not omnipresent in commercial start-ups. For example, in Fauchart and Gruber's (2011) admittedly small sample of founders with a "missionary" founder identity, all had employed non-founders, which was not the case with the other founder categories in the study. Far from conforming to the profit maximizer of basic microeconomic theory, large numbers of founders of new commercial firms lack a corresponding reason to expand their business (Carter et al. 2003; Wiklund et al. 2003). Instead, they may level off as soon as the business offers sufficient income replacement for its founder(s). 


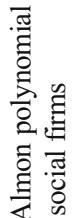

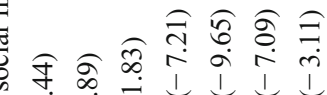

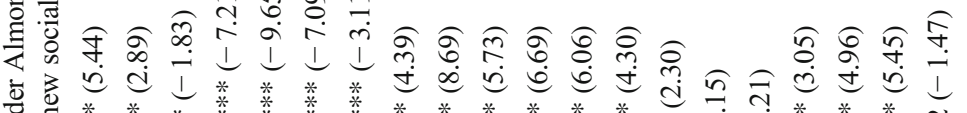

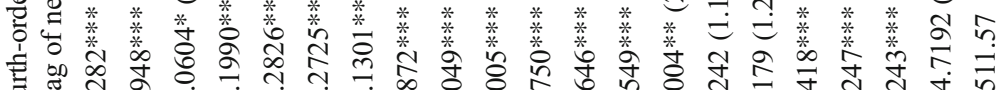

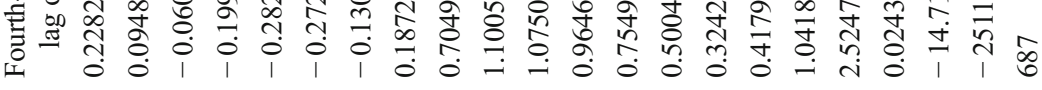

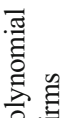

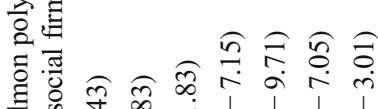

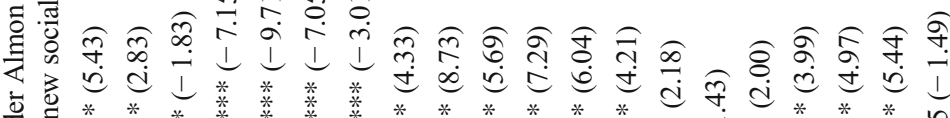

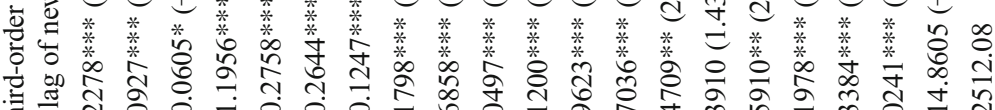
寻至

플

त产

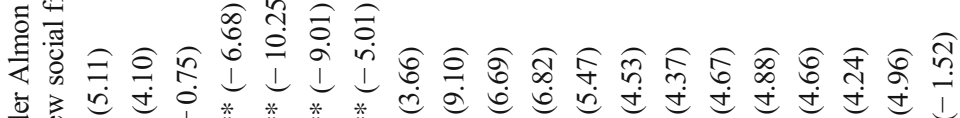

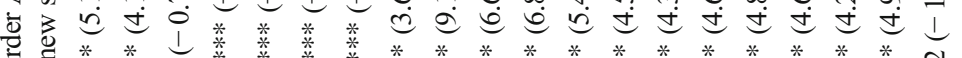

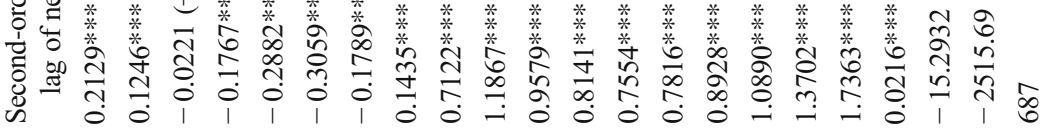

ङ艹

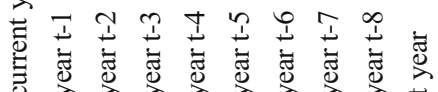

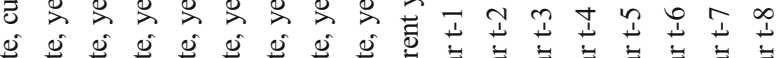

突

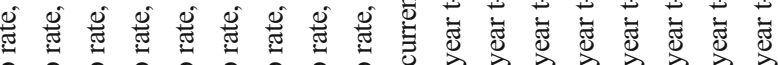

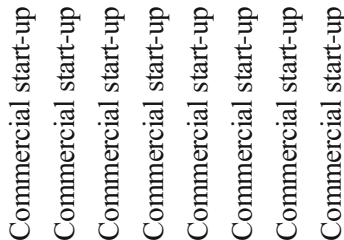




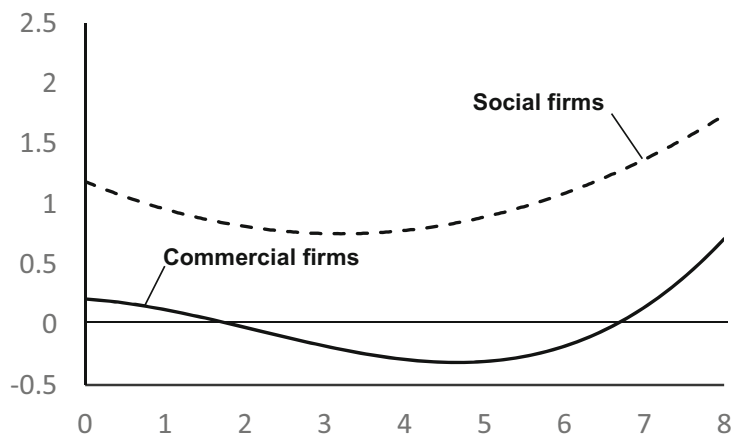

(a) Second order Almon polynomial lag of new social firms

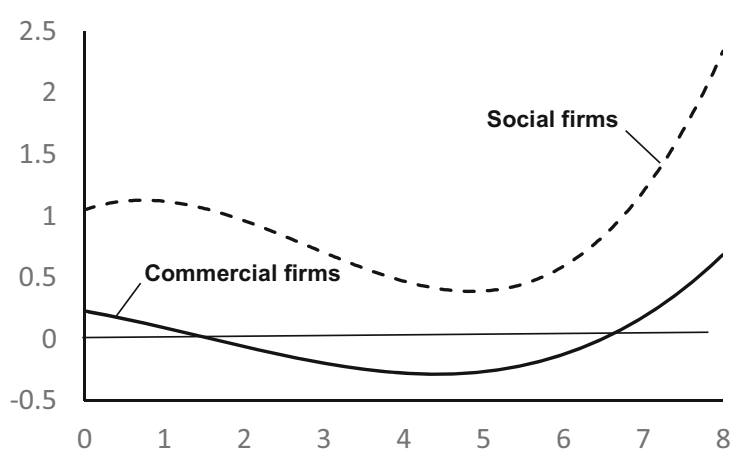

(b) Third order Almon polynomial lag of new social firms

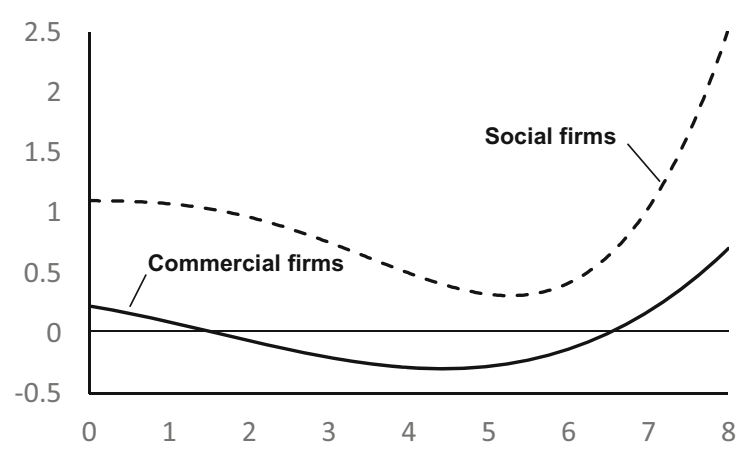

(c) Fourth order Almon polynomial lag of new social firms

Fig. 3 Polynomial Almon lag structure of the impact of both new commercial and social firms on regional employment. Third-order polynomial lag is applied for new commercial firms

Third, social entrants have competitive advantages that facilitate survival and growth. They enjoy cost advantages due to (partial) tax exemption and part of the personnel being voluntary workers (Lakdawalla and Philipson 2006). This makes it possible to offer products and services at lower prices, making growth more attainable. Moreover, some social firms benefit from the competitive advantages of acquiring legitimacy and governmental funding due to the trustworthiness that comes with their status as socially motivated (Bosma et al. 2011). It is worth noting that only the first of the three reasons for greater direct employment effect of social firm relies on an assumption of relative economic inefficiency on their part.

Partly for the same reasons social entrants may have a weaker displacement effect, which may explain why the net employment effect tends to stay positive across varying time horizons. First, the nature of social firms' missions and markets may make them less prone to crowd each other out. In line with this argument, an empirical study by Harrison and Laincz (2008) revealed very comparatively high survival rates for nonprofit social firms, whereas a similar study by Dunne et al. (1988) on commercial firms reported much lower rates of survival (see also Lakdawalla and Philipson 2006).

Second, lower productivity level of social entrants can also lead to smaller impact on displacement of incumbent firms. According to Fritsch and Mueller's (2004) framework discussed in Sect. 2, two types of exit can happen due to the entry of new firms; the exit of the start-ups and the exit of incumbents replaced by new start-ups. Social firms, as discussed above, often operate in farfrom-saturated "markets" of social needs and are thus more likely to survive the arrival of new firms addressing the same mission, resulting in a lower displacement effect compared to the effect of commercial firm entry on incumbent commercial firms. 
Third, some cases of entry occur because an entrepreneur (or self-employed person) chooses to close down one business to open another in the same year, or are a method artifact arising from change of legal form, geographical move, or industrial reclassification of an on-going business, leading to the recording of one false entry and a corresponding false exit. In these situations, the founders fully 'displace' themselves and any employees transferred across the two entities. The longer average survival reported above gives reason to believe such instances are more common among commercial than social firms. Founders driven by profit/incomereplacement can quickly move from one type of business to another when the first turns out financially less promising than expected, whereas mission-driven founders are more likely to do whatever they can to continue to address the particular social issue that motivated them to start in the first place. Further, commercial firms have more legal forms to choose from and evolve through (e.g., sole proprietorship; partnership; limited liability company), leading to greater likelihood of the methods artifact version of self-displacement.

These mechanisms could explain the apparent difference in immediate (first-year) displacement in Fig. 3b. Despite social firms relying on volunteers to a considerable extent, the social firm curve starts at a higher level and increases during the first year, whereas the curve for commercial firms points downward from the start. In all, while the above suggests social firms are less susceptible to displacement than are commercial firms, our empirical pattern suggests some displacement in the medium term, in line with Fritsch and Mueller's (2004, 2008) line of reasoning (Fig. 3b).

Lesser competitive pressure and higher survival rate would have the opposite effect on employment creation via the supply-side effect. This is because the competitive pressures of entry driving increased productivity, thereby creating a sound basis for economically viable long-term growth, would apply less to social firms than to their commercial counterparts. Whether the other part of the supply-side effectfurther entry triggered by the original entrants' example-would affect social firms differently is difficult to assess. In all, we suggest the higher net employment effect per firm attributed to social firms is likely to arise from higher direct employment and less displacement. There seems to be less reason to assume a stronger, long-term supply-side effect underlying the observed pattern.

\subsection{Other contributions}

For social entrepreneurship research our study opens up a new window for research on the economic value of social firms, whereas most existing research on new social firms focused on their social effects. Our results suggest that on a per firm basis, the net employment effect of social firm entry not only matches but exceeds that of new commercial firms. We believe this finding can inspire a new track in social entrepreneurship research focusing on the economic value of social firms besides their social value. At the same time, our results caution against viewing commercial and social firms as completely different "species" with altogether different antecedents and effects, which sometimes appears to be implicitly or explicitly assumed in social entrepreneurship research. Overall, similarity of effects is a more pronounced finding of our research than are differences.

For policy making, our results give reason to add the employment creation prowess of new social firms to their social value creation when considering policies aimed to nurture or regulate this sector. Previous research and policy has mainly considered social firms as an alleviation of negative side effects of the market economy, while their direct economic value may have been underestimated. Another policy-relevant aspect is that our results indicate that social firms to some extent may crowd out commercial enterprises, while also providing reason to reassess to which extent this is a problem.

\subsection{Limitations and future research opportunities}

Like all research, our study has some limitations that might be addressed by future research on the employment effects of social firm entrants. First, we could only include social firms registered under a particular, non-profit legal form. Although we have solid reason to believe this captures the majority of social firm start-ups, this means we could not assess the sector's total employment contribution through entry. We cannot see any reason that the particular legal form would drive important results, such as the 
higher per firm employment effect. Future studies may find ways to include a more complete and varied population of social firms with different legal structures.

Second, our study relies on Swedish data from the 1990 to 2014 period. This is a country (once) known for its well-developed welfare state during a period when some social safety systems were gradually scaled back. This may have led to particularly strong, positive effects for new social firms in our study. While a trend toward winding back welfare systems has been present in many other countries (Casey 2016), replication in similar and dissimilar economies are needed in order to determine the boundary conditions of our study's theoretical implications and their policy-relevance in other contexts (cf. Welter 2011; Zahra et al. 2014).

Third, our approach implicitly assumes homogenous effects across regions within a country. Prior studies have found regional differences regarding the employment effects of new commercial firms, related in particular to urbanization and agglomeration (e.g., Fritsch and Mueller 2008, van Stel and Suddle 2008). It was beyond the scope of our pioneering attempt to also assess regional heterogeneity of such effects, so this remains a potentially important question to address in future research. Fourth, future research could expand the topic of employment effects of new social firms by integrating other factors that have already helped to better understand employment effects of new commercial firms, such as local culture (Stuetzer et al. 2018) and historical factors (Fritsch and Storey 2014).

Some limitations and future research opportunities apply to the research stream more broadly, regardless of a particular focus on social entrants. Like those we build on, our study was conducted at the regional level, using labor market areas as empirical units. We caution against aggregation or disaggregation fallacies from inferring identical effects on country or firm levels, and believe future research addressing effects across these levels would be valuable. Finally, we chose to undertake our exploration of employment effects of social start-ups within the Fritsch and Mueller (2004, 2008) framework. This provided us with a structured approach, a basis for interpreting our results, and comparison results from other contexts, but also means that our study is subject to any general strengths and weaknesses of that particular framework, conceptual as well as methods-related. While we believe the main thrust of our results to be robust, it is possible that alternative theoretical lenses and analysis approaches could lead to partially different interpretations. An important task for future research is to find ways to assess Fritsch and Mueller's (2004, 2008) three effects-direct, displacement, and supply-side-more directly in empirical work, so as to settle any theoretical disputes and ambiguities. Following Andersson and Noseleit's (2011) example, disaggregation to look separately at different categories of commercial firms and extending such disaggregation to social firms is also desirable. Yet another avenue would be to extend the topic beyond employment rates to regional effects on wage levels, job quality, and job security. Such future research could provide a more complete and nuanced view of the various economic effects of both social and commercial new firms.

\section{Conclusion}

Regional employment creation has attracted considerable interest from both researchers and policy makers. The main focus, however, has been on the employment effects of commercial firms, with special attention to dynamics over longer periods of time. It was so far unclear whether new social firms also make a significant contribution to regional employment creation, and how such effects develop over time. Applying an approach previously used in studies not distinguishing among firm categories or including new commercial firms only, we conducted the first quantitative assessment of regional employment effects of new social firms, using data from 67 Swedish regions in 1990-2014. Our results enhance theoretical understanding of employment effects of new entry over time and highlight the important contributions of new social firms. On a per firm basis, their net employment effect is on par or above that of new commercial firms and collectively they account for a respectable share of the total variation in regional employment creation. We believe this to be of considerable importance to employment creation theory, social entrepreneurship research, and policy making. It is thus our hope that this first study and its findings will inspire research that can confirm, challenge, expand and refine our conclusions, thereby further enhancing our understanding of how both commercial and social start-ups contribute to employment and economic development.

Acknowledgments Open access funding provided by Mid Sweden University. 


\section{Appendix 1}

Table 3 Distribution of employment change, commercial start-up rate, and social start-up rate across space

Two-year regional employment change $\%($ mean $=0.80, \mathrm{SD}=1.11)$

10 regions with highest average

\begin{tabular}{lc}
\hline Göteborg & 3.2563 \\
Malmö-Lund & 2.8239 \\
Strömstad & 2.8025 \\
Jönköping & 2.7553 \\
Umeå & 2.4450 \\
Halmstad & 2.3986 \\
Eskilstuna & 2.1018 \\
Västerås & 1.9047 \\
Örebro & 1.7492 \\
Växjö & 1.6074 \\
& \\
Start-up rate of commercial firms \% (mean $=\mathbf{5 . 9 4 , ~ S D = 1 . 4 9 )}$ \\
10 regions with highest average
\end{tabular}

Stockholm-Solna

11.3016

Göteborg

9.0052

Malmö-Lund

8.4797

Årjäng

8.1087

Malung-Sälen

7.8541

Härjedalen

7.5049

Arjeplog

7.0770

Storuman

7.0051

Åsele

6.7905

Haparanda

6.7657

Start-up rate of social firms $\%($ mean $=0.68, \mathrm{SD}=0.34)$

\section{0 regions with highest average}

$\begin{array}{ll}\text { Arjeplog } & 1.9012 \\ \text { Torsby } & 1.3960 \\ \text { Arvidsjaur } & 1.3887 \\ \text { Gotland } & 1.1632 \\ \text { Härjedalen } & 1.1621 \\ \text { Vansbro } & 1.0963 \\ \text { Söderhamn } & 1.0328 \\ \text { Bollnäs-Ovanåker } & 1.0076 \\ \text { Haparanda } & 0.9549 \\ \text { Storuman } & 0.9439\end{array}$

10 regions with lowest average

$\begin{array}{lr}\text { Torsby } & -0.2922 \\ \text { Strömsund } & -0.2967 \\ \text { Storuman } & -0.3528 \\ \text { Söderhamn } & -0.6416 \\ \text { Sollefteå } & -0.8918 \\ \text { Kramfors } & -1.2613 \\ \text { Filipstad } & -1.3376 \\ \text { Hällefors } & -1.4279 \\ \text { Hagfors } & -1.6069 \\ \text { Åsele } & -1.8799\end{array}$

10 regions with lowest average

$\begin{array}{ll}\text { Hagfors } & 4.7475 \\ \text { Trollhättan-Vänersborg } & 4.7099 \\ \text { Ludvika } & 4.6925 \\ \text { Arvidsjaur } & 4.6925 \\ \text { Vansbro } & 4.5676 \\ \text { Ljungby } & 4.4975 \\ \text { Hällefors } & 4.2961 \\ \text { Oskarshamn } & 4.1737 \\ \text { Gällivare } & 4.0855 \\ \text { Filipstad } & 3.9485\end{array}$

\section{0 regions with lowest average}

Örnsköldsvik

0.4193

Västerås

0.4119

Lidköping-Götene

0.4099

Ljungby

0.4045

Trollhättan-Vänersborg

0.3966

Stockholm-Solna

0.3915

Eskilstuna

0.3842

Borås

0.3764

Jönköping

0.3654

Göteborg 
Table 4 Distribution of employment change, commercial start-up rate, and social start-up rate across time

Two-year regional employment change $\%($ mean $=0.80, \mathrm{SD}=2.25)$

10 years with highest average

2011

2007

2012

1995

2005

1999

2006

2001

2008

2002

Start-up rate of commercial firms $\%($ mean $=5.94, \mathrm{SD}=1.53)$

10 years with highest average

2010

1997

1994

2012

1998

1995

2013

2014

2008

2000

Start-up rate of social firms $\%($ mean $=0.68, S D=0.70)$

10 years with highest average

2010

1998

1997

1994

2000

1995

2006

1999

2002

2001
7.4904

7.1995

6.9593

6.7691

6.4177

6.3203

6.1201

5.9102

5.7007

5.6670
10 years with lowest average

$\begin{array}{ll}2009 & -4.3652 \\ 1997 & -3.4124 \\ 2010 & -20,206 \\ 1996 & -1.1727 \\ 2003 & -0.5280 \\ 2014 & 0.2493 \\ 2013 & 0.6586 \\ 2004 & 0.8573 \\ 1998 & 0.9728 \\ 2000 & 1.0006\end{array}$

10 years with lowest average

$\begin{array}{ll}2003 & 4.5096 \\ 2002 & 4.5387 \\ 1999 & 4.6199 \\ 2001 & 4.7288 \\ 2009 & 4.8324 \\ 2004 & 4.8661 \\ 2005 & 4.8886 \\ 2006 & 5.0278 \\ 2007 & 5.2925 \\ 1996 & 5.5684\end{array}$

10 years with lowest average

2013

2012

2008

2009

2014

2007

2003

2005

2004

1996
0.3048

0.3165

0.3261

0.3290

0.3602

0.3779

0.3960

0.4219

0.4377

0.4388 


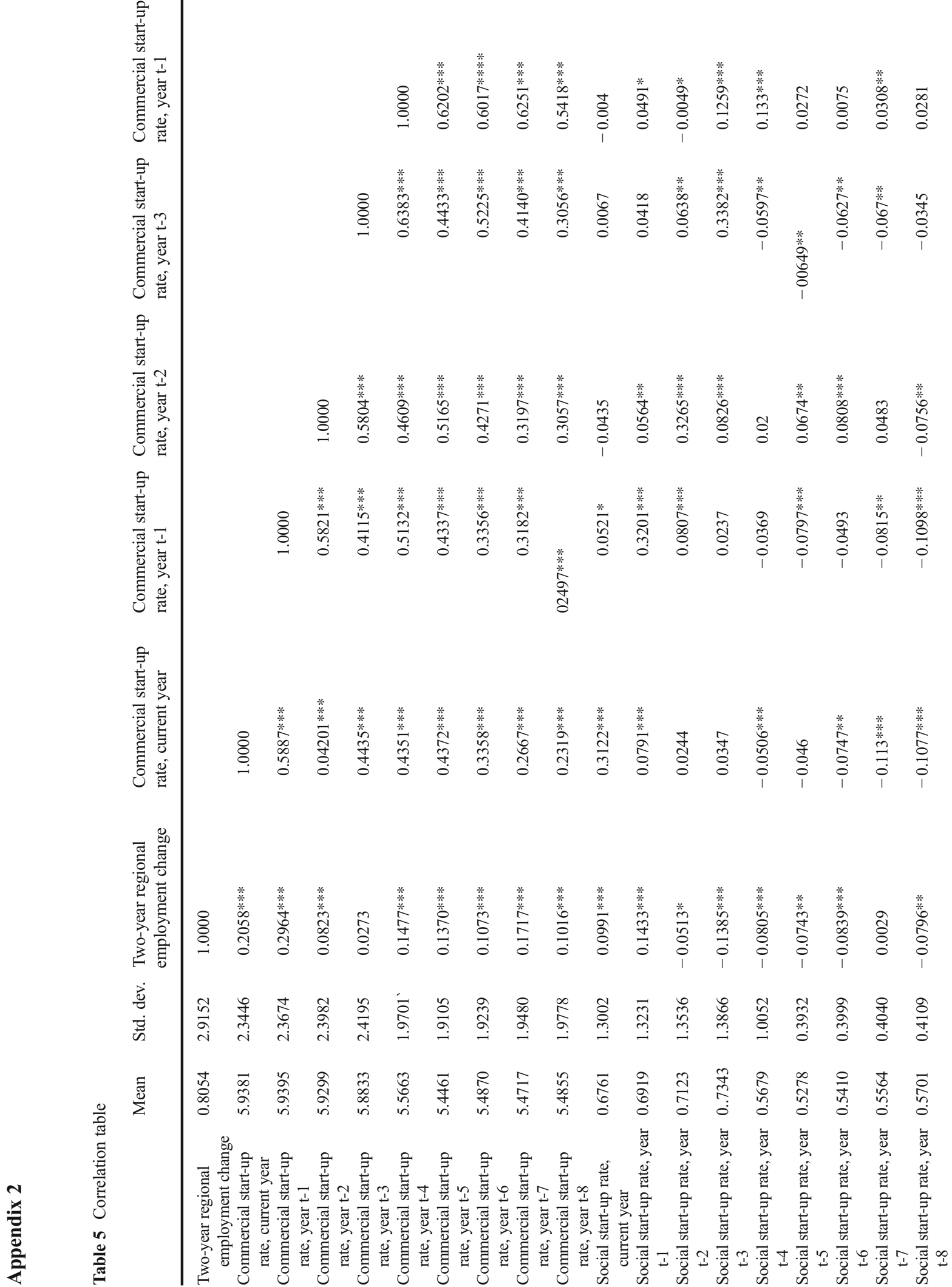

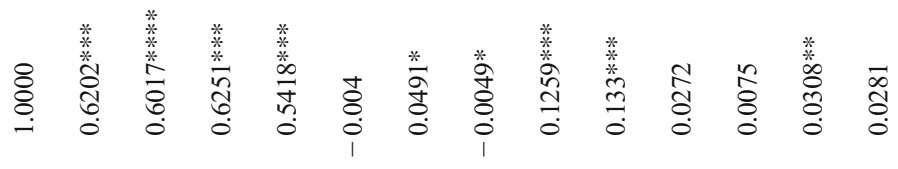

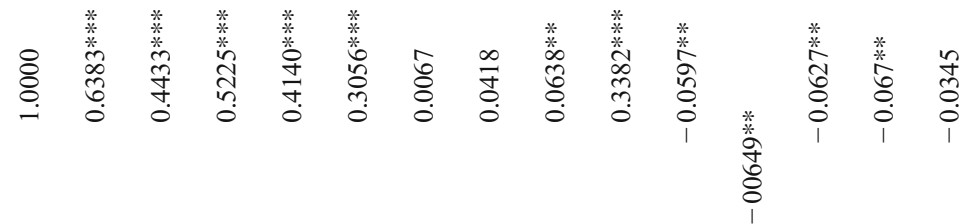




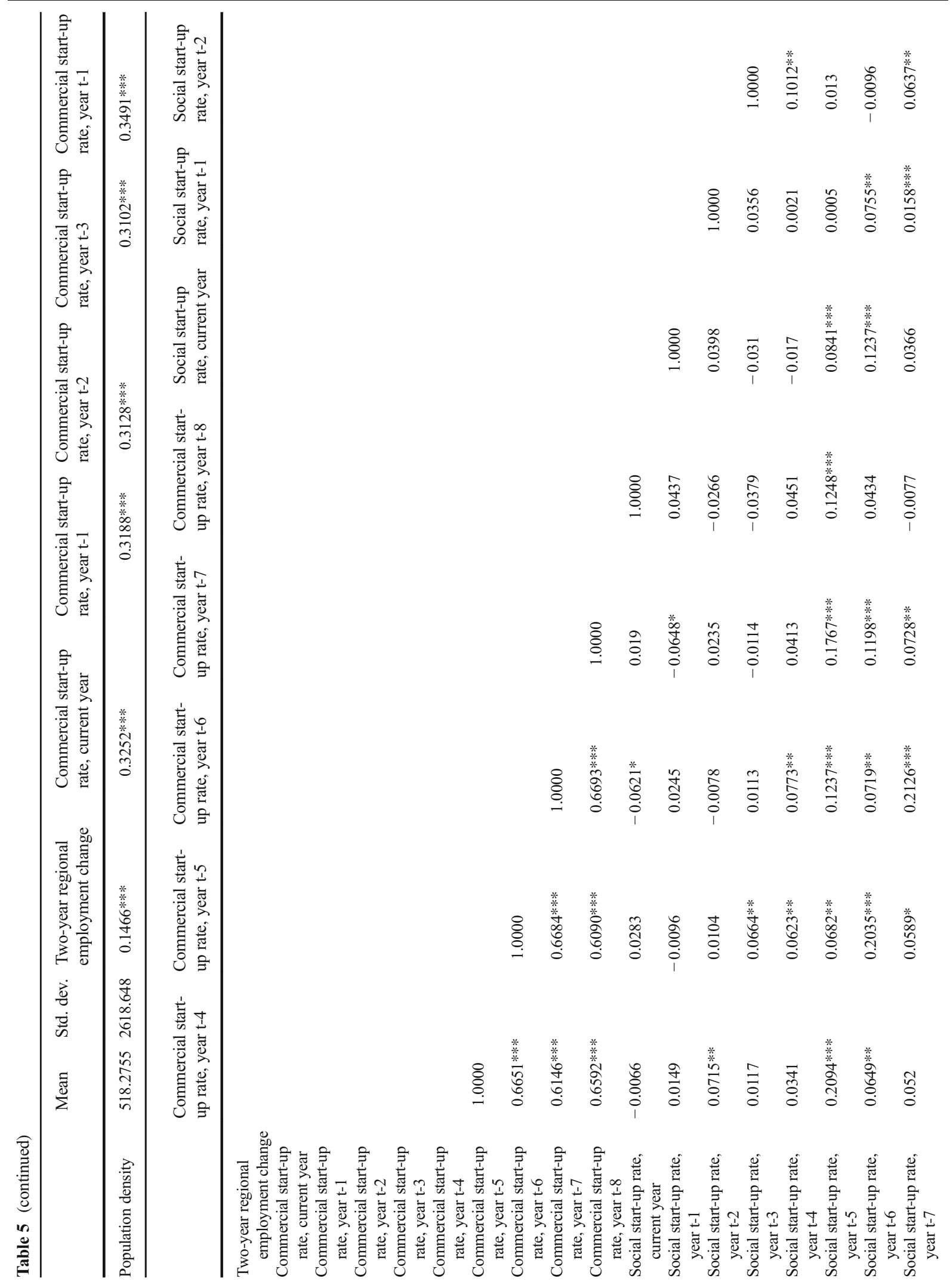




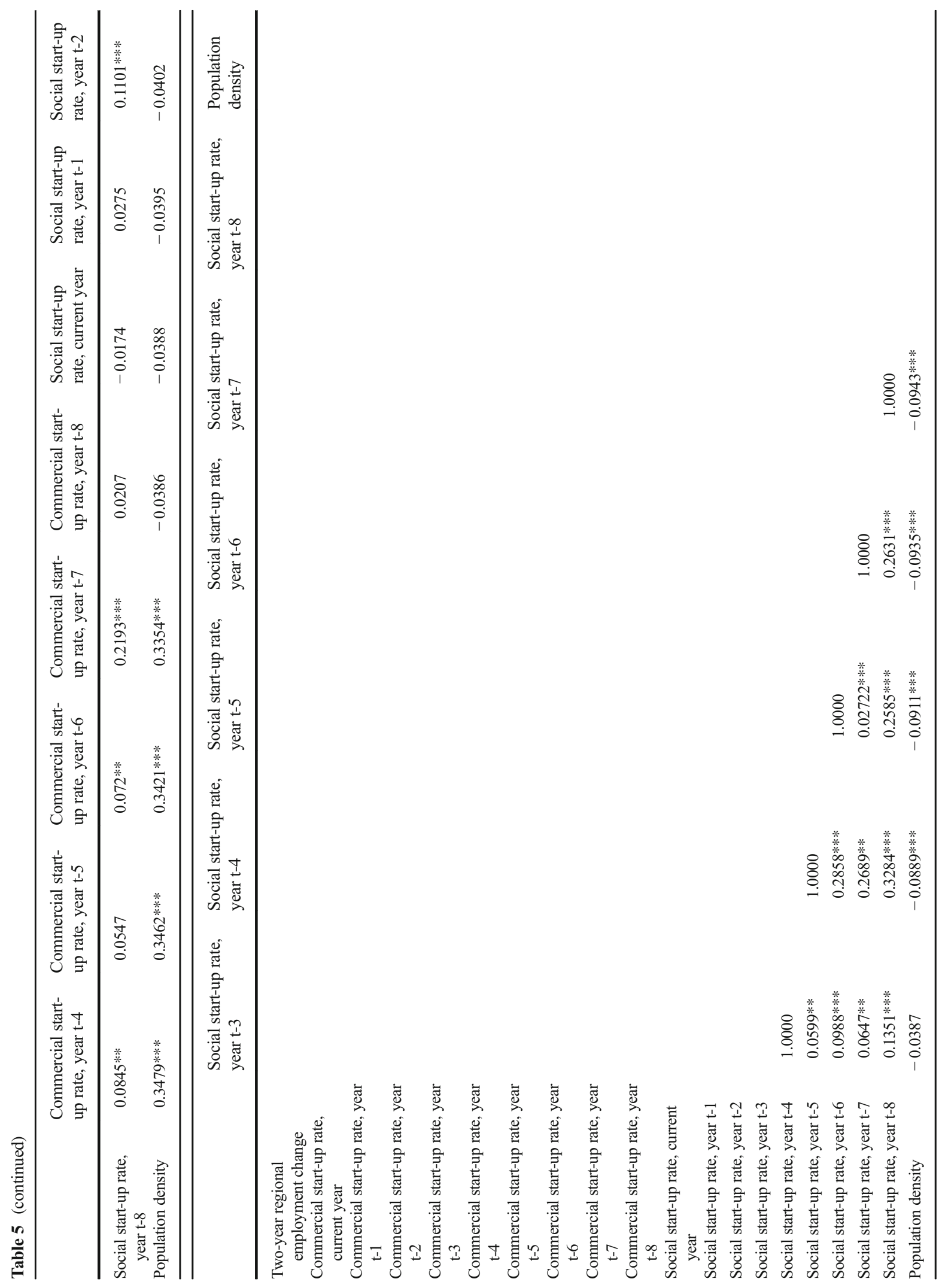


Open Access This article is licensed under a Creative Commons Attribution 4.0 International License, which permits use, sharing, adaptation, distribution and reproduction in any medium or format, as long as you give appropriate credit to the original author(s) and the source, provide a link to the Creative Commons licence, and indicate if changes were made. The images or other third party material in this article are included in the article's Creative Commons licence, unless indicated otherwise in a credit line to the material. If material is not included in the article's Creative Commons licence and your intended use is not permitted by statutory regulation or exceeds the permitted use, you will need to obtain permission directly from the copyright holder. To view a copy of this licence, visit http://creativecommons.org/licenses/by/4.0/.

\section{References}

Acs, Z. J., \& Mueller, P. (2008). Employment effects of business dynamics: Mice, gazelles and elephants. Small Business Economics, 30(1), 85-100. https://doi.org/10.1007/s11187-0079052-3.

Aldrich, H. E., \& Ruef, M. (2018). Unicorns, gazelles, and other distractions on the way to understanding real entrepreneurship in the United States. Academy of Management Perspectives, 32(4), 458-472. https://doi.org/10.5465 /amp.2017.0123.

Almon, S. (1965). The distributed lag between capital appropriations and expenditures. Econometrica: Journal of the Econometric Society, 178-196.

Andersson, F., \& Ford, M. (2016). Social entrepreneurship through an organizational ecology lens: Examining the emergence and evolution of the voucher school population in Milwaukee. Volantes: International Journal of Voluntary \& Nonprofit Organizations, 27(4), 17601780. https://doi.org/10.1007/s11266-015-9576-0.

Andersson, M., \& Koster, S. (2011). Sources of persistence in regional start-up rates - evidence from Sweden. Journal of Economic Geography, 11(1), 179-201. https://doi. org/10.1093/jeg/lbp069.

Andersson, M., \& Noseleit, F. (2011). Start-ups and employment dynamics within and across sectors. Small Business Economics, 36(4), 461-483. https://doi.org/10.1007/s11187009-9252-0.

Arauzo Carod, J. M., Liviano Soils, D., \& Martín Bofarull, M. (2008). New business formation and employment growth: some evidence for the Spanish manufacturing industry. Small Business Economics, 30(1), 73-84. https://doi.org/10.1007/s11187-0079051-4.

Archambault, E., Priller, E., \& Zimmer, A. (2014). European civil societies compared: Typically German-typically French? Voluntas: International Journal of Voluntary \& Nonprofit Organizations, 25(2), 514-537. https://doi.org/10.1007 /s11266-013-9349-6.

Audretsch, D. B., \& Fritsch, M. (1994). On the measurement of entry rates. Empirica, 21, 105-113. https://doi.org/10.1007 /BF01383974.

Audretsch, D. B., \& Fritsch, M. (2002). Growth regimes over time and space. Regional Studies, 36, 113-124. https://doi. org/10.1080/00343400220121909.
Audretsch, D. B., Grilo, I., \& Thurik, A. R. (2007). Explaining entrepreneurship and the role of policy: A framework. In D. B. Audretsch, I. Grilo, \& A. R. Thurik (Eds.), Handbook of research on entrepreneurship policy. Cheltenham: Edward Elgar publishing. https://doi.org/10.4337 /9781847206794.00005.

Austin, J., Stevenson, H., \& Wei-Skillern, J. (2012). Social and commercial entrepreneurship: Same, different, or both? RAUSP-Revista de Administração da Universidade de São Paulo, 47(3), 370-384. https://doi.org/10.5700/rausp1055.

Bacq, S., Hartog, C., \& Hoogendoorn, B. (2013). A quantitative comparison of social and commercial entrepreneurship: Toward a more nuanced understanding of social entrepreneurship organizations in context. Journal of Social Entrepreneurship, 4(1), 40-68. https://doi.org/10.1080 /19420676.2012.758653.

Baptista, R., Escária, V., \& Madruga, P. (2008). Entrepreneurship, regional development and job creation: The case of Portugal. Small Business Economics, 30(1), 49-58. https://doi. org/10.1007/s11187-007-9055-0.

Baptista, R., \& Preto, M. T. (2011). New firm formation and employment growth: Regional and business dynamics. Small Business Economics, 36(4), 419-442. https://doi. org/10.1007/s11187-009-9254-y.

Barbetta, G., Canino, P., Cima, S., et al. (2018). Entry and exit of nonprofit organizations. Nonprofit Policy Forum. https://doi. org/10.1515/npf-2017-0036.

Birch, D. L. (1981). Who creates jobs? The Public Interest, 65, 3 14.

Birch, D. L. (1987). Job creation in America. How our smallest companies put the Most people to work. New York and London: Free Press.

Borgman, B., \& Braunerhjelm, P. (2007). Entrepreneurship and local growth - a comparison of the US and Sweden, CESIS WP 103. Stockholm: Royal Institute of Technology.

Bosma, N., Stam, E., \& Schutjens, V. (2011). Creative destruction and regional productivity growth: Evidence from the Dutch manufacturing and services industries. Small Business Economics, 36(4), 401-418. https://doi.org/10.1007 /s11187-009-9257-8.

Carter, N. M., Gartner, W. B., Shaver, K. G., \& Gatewood, E. J. (2003). The career reasons of nascent entrepreneurs. Journal of Business Venturing, 18(1), 13-39. https://doi.org/10.1016 /S0883-9026(02)00078-2.

Carree, M. A., \& Thurik, A. R. (2010). The impact of entrepreneurship on economic growth. In Z. Acs \& D. Audretsch (Eds.), Handbook of Entrepreneurship Research. International Handbook Series on Entrepreneurship (Vol. 5). New York: Springer. https://doi.org/10.1007/978-14419-1191-9 20.

Casey, J. (2016). Comparing nonprofit sectors around the world. What do we know and how do we know it? Journal of Nonprofit Education and Leadership, 6(3), 187-223. https://doi.org/10.18666/JNEL-2016-V6-I3-7583.

Clarence, E., \& Noya, A. (2009). The changing boundaries of social enterprises. Paris: OECD Publishing.

Dacin, P. A., Dacin, M. T., \& Matear, M. (2010). Social entrepreneurship: Why we don't need a new theory and how we move forward from here. Academy of Management Perspectives, 24(3), 37-57. https://doi.org/10.5465/amp.24.3.37. 
Davidsson, P. (2016). Researching entrepreneurship: Conceptualization and design. New York: Springer.

Davidsson, P., \& Gordon, S. R. (2012). Panel studies of new venture creation: A methods-focused review and suggestions for future research. Small Business Economics, 39(4), 853876. https://doi.org/10.1007/s11187-011-9325-8.

Davidsson, P., Lindmark, L., \& Olofsson, C. (1994). New firm formation and regional development in Sweden. Regional Studies, 28(4), 395-410. https://doi.org/10.1080 /00343409412331348356.

Davidsson, P., Steffens, P., \& Fitzsimmons, J. (2009). Growing profitable or growing from profits: Putting the horse in front of the cart? Journal of Business Venturing, 24(4), 388-406. https://doi.org/10.1016/j.jbusvent.2008.04.003.

Dees, J. G. (2007). Taking social entrepreneurship seriously. Society, 44(3), 24-31. https://doi.org/10.1007/BF02819936.

Defourny, J., \& Nyssens, M. (2010). Conceptions of social enterprise and social entrepreneurship in Europe and the United States: Convergences and divergences. Journal of Social Entrepreneurship, 1(1), 32-53. https://doi.org/10.1080 /19420670903442053.

Dunne, T., Roberts, M. J., \& Samuelson, L. (1988). Patterns of entry and exit in U.S. manufacturing. RAND Journal of Economics, 19, 495-515 www.jstor.org/stable/2555454.

Enjolras, B., \& Strømsnes, K. (2018). The transformation of the Scandinavian voluntary sector. In B. Enjolras \& K. Strømsnes (Eds.), Scandinavian civil society and social transformations. Nonprofit and civil society studies (an international multidisciplinary series). Cham: Springer.

Fauchart, E., \& Gruber, M. (2011). Darwinians, communitarians, and missionaries: The role of founder identity in entrepreneurship. Academy of Management Journal, 54(5), 935-957. https://doi.org/10.5465/amj.2009.0211.

Fritsch, M. (2008). How does new business formation affect regional development? Introduction to the special issue. Small Business Economics, 30(1), 1-14. https://doi. org/10.1007/s11187-007-9057-y.

Fritsch, M. (2015). Methods of analyzing the relationship between new business formation and regional development. In C. Karlsson, M. Andersson, \& T. Norman (Eds.), Handbook of research methods in economic geography. Cheltenham: Edward Elgar.

Fritsch, M., \& Mueller, P. (2004). Effects of new business formation on regional development over time. Regional Studies, $38(8), 961-975$. https://doi.org/10.1080 $/ 0034340042000280965$.

Fritsch, M., \& Mueller, P. (2008). The effect of new business formation on regional development over time: The case of Germany. Small Business Economics, 30(1), 15-29. https://doi.org/10.1007/s11187-007-9067-9.

Fritsch, M., \& Noseleit, F. (2013). Investigating the anatomy of the employment effect of new business formation. Cambridge Journal of Economics, 37(2), 349-377. https://doi. org/10.1093/cje/bes030.

Fritsch, M., \& Schindele, Y. (2011). The contribution of new businesses to regional employment - an empirical analysis. Economic Geography, 87(2), 153-180. https://doi. org/10.1111/j.1944-8287.2011.01113.x.

Fritsch, M., \& Schroeter, A. (2011). Why does the effect of new business formation differ across regions? Small Business
Economics, 36(4), 383-400. https://doi.org/10.1007 /s11187-009-9256-9.

Fritsch, M., \& Storey, D. J. (2014). Entrepreneurship in a regional context: Historical roots, recent developments and future challenges. Regional Studies, 48(6), 939-954. https://doi. org/10.1080/00343404.2014.892574.

Fölster, S. (2000). Do entrepreneurs create jobs? Small Business Economics, 14(2), 137-148. https://doi.org/10.1023 /A:1008141516160.

Garrow, E. E., \& Hasenfeld, Y. (2014). Social enterprises as an embodiment of a neoliberal welfare logic. American Behavioral Scientist, 58(11), 1475-1493. https://doi. org/10.1177/0002764214534674.

Greene, W. H. (2008). Econometric analysis (6th ed.). Upper Saddle River: Pearson.

Haltiwanger, J., Jarmin, R. S., \& Miranda, J. (2013). Who creates jobs? Small versus large versus young. Review of Economics and Statistics, 95(2), 347-361. https://doi.org/10.1162 /REST a 00288 .

Hansmann, H. (1980). The role of nonprofit enterprise. Yale Law Journal, 89(5), 835-901. https://doi.org/10.1007/978-14615-0131-2 6.

Hansmann, H. (1987). The effect of tax exemption and other factors on the market share of nonprofit versus for-profit firms. National Tax Journal, 40(1), 71-82.

Harding, R., \& Cowling, M. (2006). Social entrepreneurship monitor. London: Global Entrepreneurship Monitor.

Harrison, T. D., \& Laincz, C. A. (2008). Entry and exit in the nonprofit sector. The B.E. Journal of Economic Analysis and Policy, 8(1), 1-41. https://doi.org/10.2202/1935-1682.1937.

Harrison, T. D., \& Thornton, J. (2014). Too many nonprofits? An empirical approach to estimating trends in nonprofit demand density. Nonprofit Policy Forum, 5(2), 213-229. https://doi. org/10.1515/npf-2014-0009.

Henry, C., Treanor, L., Griffiths, M. D., Gundry, L. K., \& Kickul, J. R. (2013). The socio-political, economic, and cultural determinants of social entrepreneurship activity. Journal of Small Business and Enterprise Development, 20(2), 341357. https://doi.org/10.1108/14626001311326761.

Hoogendoorn, B., Pennings, E. \& Thurik, R. (2010). What do we know about social entrepreneurship: An analysis of empirical research. ERIM Report Series Reference No. ERS-2009044-ORG. Available at SSRN: https://ssrn. com/abstract=1462018

Kachlami, H. (2016). Social venture creation and the influence of commercial ventures. Social Enterprise Journal, 12(3), 347 367. https://doi.org/10.1108/SEJ-02-2016-0006.

Kachlami, H. (2017). Regional dynamism between social and commercial ventures: An empirical study based on Swedish data. International Journal of Social Economics, 44(9), 1122-1138. https://doi.org/10.1108/IJSE-11-2015-0293.

Kachlami, H., Yazdanfar, D., \& Öhman, P. (2018). Regional demand and supply factors of social entrepreneurship. International Journal of Entrepreneurial Behavior \& Research, 24(3), 714-733. https://doi.org/10.1108/IJEBR09-2016-0292.

Kirchhoff, B. A. (1994). Entrepreneurship and dynamic capitalism: The economics of business firm formation and growth. Westport: Praeger. 
Lakdawalla, D., \& Philipson, T. (2006). The nonprofit sector and industry performance. Journal of Public Economics, 90(8), 1681-1698. https://doi.org/10.1016/j.jpubeco.2005.11.004.

Lecy, J. D., \& Van Slyke, D. M. (2013). Nonprofit sector growth and density: Testing theories of government support. Journal of Public Administration Research and Theory, 23(1), 189214. https://doi.org/10.1093/jopart/mus010.

Lundström, T., \& Svedberg, L. (2003). The voluntary sector in a social democratic welfare state-the case of Sweden. Journal of Social Policy, 32(2), 217-238. https://doi.org/10.1017 /S0047279402007006.

Mair, J., \& Marti, I. (2006). Social entrepreneurship research: A source of explanation, prediction, and delight. Journal of World Business, 41(1), 36-44. https://doi.org/10.1016/j. jwb.2005.09.002.

Moretti, E. (2010). Local multipliers. American Economic Review, 100(2), 373-377. https://doi.org/10.1257/aer.100.2.373.

Mueller, P., van Stel, A., \& Storey, D. J. (2008). The effects of new firm formation on regional development over time: The case of Great Britain. Small Business Economics, 30(1), 59-71. https://oi.org/10.1007/s11187-007-9056-z.

Nicholls, A. (2010). The legitimacy of social entrepreneurship: Reflexive isomorphism in a pre-paradigmatic field. Entrepreneurship Theory and Practice, 34(4), 611-633. https://doi.org/10.1111/j.1540-6520.2010.00397.x.

OECD. (2013). Policy brief on social entrepreneurship (p. 2013). Luxembourg: Publications Office of the European Union.

Parker, S. C. (2018). The economics of entrepreneurship. Cambridge: Cambridge University Press.

Peredo, A. M., \& McLean, M. (2006). Social entrepreneurship: A critical review of the concept. Journal of World Business, 41(1), 56-65. https://doi.org/10.1016/j.jwb.2005.10.007.

Salamon, L. M. (2012). The resilient sector: The future of nonprofit America. In L. M. Salamon (Ed.), The State of Nonprofit America (pp. 3-89). Washington, DC: Brookings institution press.

Salamon, L. M., \& Sokolowski, W. (2018). The size and composition of the European third sector. In B. Enjolras, L. M. Salamon, K. H. Sivesind, \& A. Zimmer (Eds.), The Third Sector as a Renewable Resource for Europe. London: Palgrave Macmillan. https://doi.org/10.1007/978-3-31971473-8.

Seelos, C., Mair, J., Battilana, J., \& Tina Dacin, M. (2011). The embeddedness of social entrepreneurship: Understanding variation across local communities. In C. Marquis, M. Lounsbury, \& R. Greenwood (Eds.), Communities and Organizations (Research in the Sociology of Organizations, Vol. 33). Bingley: Emerald Group publishing limited. https://doi.org/10.1108/S0733-558X(2011)0000033013.

Short, J. C., Moss, T. W., \& Lumpkin, G. T. (2009). Research in social entrepreneurship: Past contributions and future opportunities. Strategic Entrepreneurship Journal, 3(2), 161-194. https://doi.org/10.1002/sej.69.
Sivesind, K. H. (2017). The changing roles of for-profit and nonprofit welfare provision in Norway, Sweden, and Denmark. In K. Sivesind \& J. Saglie (Eds.), Promoting Active Citizenship. Palgrave Macmillan. https://doi. org/10.1007/978-3-319-55381-8.

Stuetzer, M., Audretsch, D. B., Obschonka, M., Gosling, S. D., Rentfrow, P. J., \& Potter, J. (2018). Entrepreneurship culture, knowledge spillovers and the growth of regions. Regional Studies, 52(5), 608-618. https://doi.org/10.1080 /00343404.2017.1294251.

Twombly, E. C. (2003). What factors affect the entry and exit of nonprofit human service organizations in metropolitan areas? Nonprofit and Voluntary Sector Quarterly, 32(2), 211-235. https://doi.org/10.1177/0899764003032002003.

Van Stel, A. J., \& Storey, D. J. (2004). The link between firm births and job creation: Is there a Upas tree effect? Regional Studies, $38(8), 893-909$. https://doi.org/10.1080 $/ 0034340042000280929$.

Van Stel, A., \& Suddle, K. (2008). The impact of new firm formation on regional development in the Netherlands. Small Business Economics, 30(1), 31-47. https://doi. org/10.1007/s11187-007-9054-1.

Vidal, I. (2005). Social enterprise and social inclusion: Social enterprises in the sphere of work integration. International Journal of Public Administration, 28(9), 807-825. https://doi.org/10.1081/PAD-200067347.

Weisbrod, B. A. (1977). The voluntary nonprofit sector: An economic analysis. Lexington Books: Lexington.

Welter, F. (2011). Contextualizing entrepreneurship - Conceptual challenges and ways forward. Entrepreneurship Theory and Practice, 35(1), 165-184. https://doi.org/10.1111/j.15406520.2010.00427.x.

Wiklund, J., Davidsson, P., \& Delmar, F. (2003). What do they think and feel about growth? An expectancy-value approach to small business managers' attitudes toward growth. Entrepreneurship Theory and Practice, 27(3), 247-270. https://doi.org/10.1111/1540-8520.t01-1-00003.

Zahra, S. A., Gedajlovic, E., Neubaum, D. O., \& Shulman, J. M. (2009). A typology of social entrepreneurs: Motives, search processes and ethical challenges. Journal of Business Venturing, 24(5), 519-532. https://doi.org/10.1016/j. jbusvent.2008.04.007.

Zahra, S. A., Wright, M., \& Abdelgawad, S. G. (2014). Contextualization and the advancement of entrepreneurship research. International Small Business Journal, 32(5), 479500. https://doi.org/10.1177/0266242613519807.

Publisher's note Springer Nature remains neutral with regard to jurisdictional claims in published maps and institutional affiliations. 